\title{
Student Interaction, Teacher Competence, and Technology in Online Learning: Does it Create a Meaningful Learning?
}

\author{
Adelina gultom ${ }^{1, *}$ Suhartini ${ }^{2}$ \\ ${ }^{1}$ Master of Biology Education, Faculty of Mathematics and Natural Sciences, Universitas Negeri Yogyakarta, \\ Indonesia \\ ${ }^{2}$ Department of Biology Education, Faculty of Mathematics and Natural Sciences, Universitas Negeri \\ Yogyakarta, Indonesia \\ *Corresponding author. Email: adelinagultom.2019@student.uny.ac.id
}

\begin{abstract}
Online learning during the Covid-19 pandemic certainly has a changed learning environment than previous learning. Previous learning activities before the pandemic occurred allowed face to face interaction. The form of the role of student-teacher interactions in delivering online learning is the topic of focus in this article. Teacher competence is a variable that cannot be separated from any learning and mastery of software application technology to support learning activities. The electronic learning program as a medium must be able to adapt to the current pandemic conditions. It influences on how deep online learning is carried out so that full meaningful learning is realized. Technology, which includes devices, internet quotas and signals, has become a strong criticism of the unpreparedness of these educational service providers to facilitate online learning.
\end{abstract}

Keywords: Student interaction, Teacher competence, Technology, Online learning, Meaningful learning

\section{INTRODUCTION}

The implementation of online learning is a policy carried out by several schools in Indonesia to respond the Covid-19 pandemic effect. The Ministry of Education and Culture of the Republic of Indonesia address the policy, indirect or online learning can enable teachers and students to do learning during the pandemic.

Learning process must create meaningful learning. The essence of meaningful learning is learning that has a special approach and strategy in linking new knowledge with previous student knowledge so that learning can be easily understood. Surely, meaningful learning is a form of good learning. Factors that influence good learning is having a good learning environment as well, which can be influenced by several aspects, including interaction, and teacher competence. In this sense, digital technology is very important in online learning. Technology is a solution in implementing distance learning during the Covid19 pandemic. Thus, online learning can be carried out anywhere and anytime and with anyone by teachers and students [1].

Interaction plays a vital role in the learning process. Interaction is very important because in the teaching and learning process, a close, boundless relationship between the teaching staff and students must be built so that the knowledge provided can be well received [2]. It is very important to assess the success of students in understanding that the value of e-learning is more effective than conventional methods. Several studies have shown that students' incomprehension through online learning is higher compared to face-to-face learning due to lack of interaction.

Teaching in a place that is expert in technology is very challenging, teachers must have qualified skills and better competencies to produce successful learning. To provide IT instructors with the skills and competencies are necessary for successful online learning [3]. The use of technology in learning acts as a liaison for proper learning without eliminating direct learning. To support online learning, the use of the 
internet and multimedia technology includes the use of applications such as virtual classes with Google Classroom, Google Meet, WhatsApp and so on [4].

Online learning should not reduce the quality of meaningful learning that everyone wants. The question is, has the online learning implemented have made meaningful learning happen? Are there good interactions between students and teachers in online learning? Is the teacher's ability to implement strategies and learning approaches and operate technology in online learning maximized already? Does the technology used in online learning meet the learning needs appropriately? Have student-teacher interactions, teacher competence and technology manifested meaningful learning? Therefore, this article identifies student-teacher interactions, teacher competence and technology in online learning in realizing meaningful learning through literature review research.

\section{RESEARCH METHODS}

The method used is a methodical literature review, which is a literature review method that identifies, evaluates and interprets all finding on research topic to solve formerly determined research questions (Kitchenham \& Charters, 20017). The search for articles was done online by using the search words "online learning", and "meaningful learning".

The method used is the preferred reporting item for systematic review and meta-analytic method. All articles that have passed the selection process were then reviewed and summarized based on the objective, author's name, year of publication, number of respondents, instruments used, research results and suggestions for further research. The search process begins by reviewing the titles and abstract of the entire search result and comparing them with established criteria. The research database search result in all keywords search result obtained 42 research articles, after scanning the title, there was the same article in two databases. The articles are compared to find the answers the questions about online learning, student interaction and technology. Furthermore, student and teacher interaction factors, teacher competence and the role of technology were identified and then stated whether it is capable to create a meaningful online learning environment in today's online learning.

\section{RESULTS AND DISCUSSION}

\subsection{Student-Teacher Interactions in Online Learning}

Dialogue or interaction is an important variable in the online learning environment. To take advantage of online learning, changes in student-teacher interactions must be considered [5]. This interaction realizes critical learning and deeper exploration of knowledge. Although student-teacher interactions are not fully associated with increasing cognitive abilities, interactions are directed at cognitive outcomes and character. Interaction through the environment during the learning procedure force stimulate all pupils' senses and encourage them to learn creatively and innovatively [6].

This fact will affect students' reasoning and prevent them from remembering only data and experience to being critical. Teachers be able to build the classroom environment more comfort because it can increase students' skill to understand. Openness between students and teachers make a comfort classroom environment. These provide an information that teacher-student interaction, suitability of the learning environment, commitment of students to learning and positive learning comfort. There is a correlation between the interaction of the student's teacher, the ability of the learning environment and the persistence of learning with the convenience of learning. Further studies also show that the two main factors that contribute to the convenience of learning are the commitment to learning and the learning environment [7]. Teachers need to use a variety of methods and strategies in online learning in a way that is more interesting in the class. Teachers can get group activities to develop communication and interaction among learners and promote active participation of the students.

There are seven effective online teaching principles that serve as an assessing agenda to improve the quality of conventional learning experiences. The principle is that there is contact between teachers and students and cooperation between students, encouraging active learning, providing quick feedback, time discipline on assignments, conveying high expectations, and appreciating students' different talents and learning styles.

There are some principles that have been applied in e-learning environments to differing degrees. Evaluators use these seven principles as their standards for assessing teaching and learning in an elearning environment. This information based by 
Table 1. Research on interactions in learning

\begin{tabular}{|c|c|c|c|}
\hline Author \& Year & Purpose of Studies & Method & Conclusions \\
\hline $\begin{array}{l}\text { Don Bouhnik \& } \\
\text { Tali marcus. } 2018\end{array}$ & $\begin{array}{l}\text { To find out the role of } \\
\text { interaction in learning. }\end{array}$ & $\begin{array}{l}\text { Quasi } \\
\text { experiment }\end{array}$ & $\begin{array}{l}\text { Interaction has a role in the success of } \\
\text { learning in the classroom. Good } \\
\text { interaction will generate benefits for } \\
\text { students and positive learning outcomes. }\end{array}$ \\
\hline $\begin{array}{l}\text { Christenson, } \\
\text { Sandra L, } 2012\end{array}$ & $\begin{array}{l}\text { to find out the student-teacher } \\
\text { relationship and the } \\
\text { interaction and the quality of } \\
\text { the interaction between the } \\
\text { teacher and the relationship } \\
\text { student involvement in } \\
\text { learning. }\end{array}$ & $\begin{array}{l}\text { Multilevel } \\
\text { analysis }\end{array}$ & $\begin{array}{l}\text { Interaction is in the form of student- } \\
\text { content, student-teacher and student- } \\
\text { student interactions. Care should be taken } \\
\text { in structuring online learning to form } \\
\text { feelings of closeness. Proximity does not } \\
\text { mean distance but the relationship } \\
\text { between participants in learning }\end{array}$ \\
\hline $\begin{array}{c}\text { Joana cadima, } \\
2010\end{array}$ & $\begin{array}{l}\text { Associating the quality of } \\
\text { student-teacher interactions, } \\
\text { class interactions are } \\
\text { important to improve } \\
\text { academic skills }\end{array}$ & Experiment & $\begin{array}{l}\text { With good interaction, warm and sensitive } \\
\text { produce good reasoning. The interaction } \\
\text { of student teachers in learning can } \\
\text { provide high language and reasoning skills }\end{array}$ \\
\hline Jason T Downer & $\begin{array}{l}\text { To see the effectiveness of } \\
\text { student and teacher } \\
\text { interactions }\end{array}$ & $\begin{array}{l}\text { Multilevel } \\
\text { analysis }\end{array}$ & $\begin{array}{l}\text { Students with high interaction intensity } \\
\text { throughout learning have the potential to } \\
\text { add unique understanding and } \\
\text { perspectives and be able to develop an } \\
\text { atmosphere in the classroom }\end{array}$ \\
\hline $\begin{array}{l}\text { Shu-shung liaw } \\
\text { (2012) }\end{array}$ & $\begin{array}{l}\text { To investigate self-regulation } \\
\text { and learning attitudes towards } \\
\text { e-learning }\end{array}$ & $\begin{array}{l}\text { Survey } \\
\text { research }\end{array}$ & $\begin{array}{l}\text { Interactive learning has a fun learning } \\
\text { environment. Students feel satisfied and } \\
\text { have high self-confidence. }\end{array}$ \\
\hline $\begin{array}{l}\text { Gerda Hagenour, } \\
2014\end{array}$ & $\begin{array}{l}\text { Reviewing the relationship } \\
\text { between student-teacher and } \\
\text { the importance of overcoming } \\
\text { multi-dimensional related } \\
\text { student-teacher relationships }\end{array}$ & $\begin{array}{l}\text { Multilevel } \\
\text { analysis }\end{array}$ & $\begin{array}{l}\text { Student-teacher interactions based on } \\
\text { frequency and quality will produce student } \\
\text { teacher relationships that include } \\
\text { dimensions of attitude and support. The } \\
\text { consequent relationship between students } \\
\text { and teachers will result in quality teaching } \\
\text { and learning activities. }\end{array}$ \\
\hline $\begin{array}{l}\text { C.Catherine, } \\
\text { W,C.Sonnenberg, } \\
2014\end{array}$ & $\begin{array}{l}\text { Knowing the form of student } \\
\text { and teacher interaction in } \\
\text { online learning }\end{array}$ & Experiment & $\begin{array}{l}\text { In the current paradigm, the SCL approach } \\
\text { is teacher's domination. } \\
\text { reduced in interaction because the teacher } \\
\text { considers himself to be only a facilitator } \\
\text { and not the only source of learning. The } \\
\text { teacher in facilitating students aims so that } \\
\text { students can enjoy learning anywhere, }\end{array}$ \\
\hline
\end{tabular}




\begin{tabular}{|l|l|l|l|}
\hline Author \& Year & \multicolumn{1}{|c|}{ Purpose of Studies } & \multicolumn{1}{|c|}{ Method } & \multicolumn{1}{|c|}{ Conclusions } \\
\hline & & & $\begin{array}{l}\text { whenever students need educational } \\
\text { services. }\end{array}$ \\
\hline $\begin{array}{l}\text { R-C.Pianta, J- } \\
\text { Whittaker, 2020 }\end{array}$ & $\begin{array}{l}\text { Knowing the form of student } \\
\text { interaction during online } \\
\text { learning }\end{array}$ & $\begin{array}{l}\text { Experiment } \\
\text { (n) }\end{array}$ & $\begin{array}{l}\text { Online learning is learning that makes } \\
\text { students independent without depending } \\
\text { on others. In online learning, students } \\
\text { focus on the screen of the device to } \\
\text { complete a given task or follow an } \\
\text { ongoing discussion. No interaction takes } \\
\text { place in the form of unnecessary talk. }\end{array}$ \\
\hline
\end{tabular}

student feedback, the evaluator developed a list of lessons learned, according to each source. The result was a specific set of guidelines related to each principle, which was much more useful for educators who want to increase the effectiveness of their teaching and need more specific strategies to implement immediately.

The Consortium (OLC) states in their Five Pillars of Online Education Quality "Student satisfaction reflects the effectiveness of all aspects of the educational experience". OLC also noted that the most critical key to continuous learning is student satisfaction. Finally, there is research that shows that student satisfaction can decrease wear rates and influence students to take more online learning.

In a study involving 397 students, et al. (2006) identified several important factors for student happiness related to teacher relations. Learning highlights that learners want regular feedback from teachers, teacher assistance of in-course learning, and teachers who have strong subject knowledge. In a similar study, performed over three years at a university, researchers surveyed 553 apprentice and former students to investigate levels of satisfaction in e-learning.

Results showed $46 \%$ of students were satisfied with their online learning, citing convenience, structure, and learning preferences as reasons. The data shows $54 \%$ of students are not satisfied with their e-learning. The highest reason for reported unhappiness, noted by $33 \%$ of students, was shortage of teacher and peer interaction. Another $8 \%$ of students are dissatisfied with their teacher skills with online learning instruction. This is add to the evidence that e-learning interaction is related to student enjoyment.
Interactions associated with student achievement and the interactions student knowledge in an elearning environment are different from conventional learning. The example, in a conventional classroom, the interaction between teacher and student built close the psychological distance. Many e-learning teachers have limited examples for written communication and lose the benefit of voice gestures or body language. What remains the same is that interaction is an essential element in any type of educational setting, perhaps if not more so in an online environment [3].

Student interaction implies to how students interact with schoolbooks, instructional videos, and other e-learning materials. This form of contact tends to be one-sided because information emerges to students from the subject matter. Student-teacher interactions include asynchronous communication via discussion boards and e-mail the same as well as synchronous communication via chat and video conferencing. This form of interaction is a two-way communication between students and teachers. High quality and frequency of student-teacher interactions are necessary to have a successful distance learning experience. Student-student interaction refers to communication between students. This interaction includes cooperative learning can help develop critical thinking skills and deeper knowledge [8].

Several studies have documented students' desire for interpersonal communication and that less student interaction can lead to higher levels of attrition. Some researches show this communication has little or no great effect on student happiness while others report that research helps improve achievement. Interaction needs will differ in every online lesson depending to the type of student, teacher personality and philosophy, and course design. Educators and teachers must be made aware of the importance of the 
interactions that occur in their online learning. They must continue to look for ways to overcome communication difficulties in the online environment, expand opportunities for content influence, and seek new ways for students to connect with others [8].

Based on the findings that effective online education relies on 1) well-designed course content, encouraged interactions between instructure and students, well-organized and totally supported instructors; 2) creating a sense of e-learning community; and 3) rapid technological development. It is hoped that it will encourage continuing discussion about efficient strategies that can enhance the success school in the transition to e-learning of teaching. That can help increase higher education as well as student enrolment and retention [10].

\subsection{Technology}

Technology, online education, and students are constantly changing. When technological innovations occur affecting the Internet and computer software, we need to imagine about new developments for elearning. Educators require to provide an innovative experience for every student. Educators should think a different approach to e-learning design and development that takes mobile responsiveness into account. The goal is to create a mobile visual framework more friendly and enables comprehensive showing in any online environment. It should be considered that e-learning can be done anywhere, anytime, the growing number of mobile tools can lead to new e-learning directions. This guidance, using collaboration devices, can enable professors, students, and remote experts to connect visually with each other. Collaboration tools can make data more available and can generate new online learning models. Collaboration tools and those applications can create borderless online networking models. Thus, a borderless networking approach can create dynamic online learning opportunities. Before lurking online education, one must define the technology that makes the online landscape possible. Technology is the product of materials, processes, techniques, and tools to human activities [20].

Technology in schools is often underutilized, so we need a way to incorporate technology education into the school curriculum and assess students' technological literacy skills [21].

Online learning during this pandemic seems to be a moment for the application of online learning using technology to be faster in application. Educators have their own challenges in dealing with millennial students in this online learning. Student access to digital technology is not an extraordinary thing, but it is a major requirement so that students can fully participate in getting high-quality educational opportunities. Information Technology and Computers (ICT) are important things that teachers and students use in accessing knowledge. Teachers and students are required to have the ability to create a learning environment that affects the learning process in understanding, testing, measuring, and evaluating from the aspects of knowledge, skills and attitudes. So that the learning environment that is strengthened by technology must represent the efforts of all parties, both educators, students, policy makers, school leaders and so on. All parties must be involved and support efforts to establish meaningful online learning [22].

Online learning is not without obstacles. There are several obstacles to online learning in terms of technology, namely limited ownership of quotas for students and teachers, too many assignments given by the teacher, limited mastery of applications and IT, network instability, learning delays, even non-existent networks for students living inland. Some students stated that these obstacles greatly affect the psychological condition of students. This psychological condition must be anticipated by students and teachers together considering that psychological health is important in the work of the brain in learning [23].

Some of the applications used in online learning are Zoom, Google Classroom, Google Form, Teacher Room, Google Doc, Telegram, YouTube, video conference and WhatsApp. Online learning with this application can run well, effectively, and meaningfully if it is adjusted to the creativity of the teacher in choosing the right strategy and approach. Teacher creativity is required in conveying knowledge through online learning. Video conference, google meet, zoom can be used to interact with students. Explaining in more detail and communication about knowledge can help the interactions needed in meaningful learning. This can even provide an advantage over direct learning, as this interaction can be carried out in a more flexible manner. Whereas other applications such as Google Classrooms, Google Doc, Telegram, YouTube, and WhatsApp can be used by teachers as a forum for students to communicate through writing and collect various assignments given by the teacher. Monitoring student performance can also be done through this application. All teaching and learning processes can run well, not only do it, of course, need supervision so that these activities run effectively and efficiently. Technology in the form of learning applications can also be implemented by teachers to 
coordinate with parents. So that interactions are not only intertwined with students and teachers but students, teachers and parents.

There are several schools that have not been able to carry out online learning optimally. Lack of teacher innovation in shaping meaningful e-learning and in choosing alternative learning media during online learning. But online learning shows positive student interest, students are more excited about participating in online learning and do not feel bored during thr learning [24].

There is also research which states that google classroom basic education can be used in direct learning. This learning is called blended learning. Blended learning is the combination of two direct and online learning methods to create a sense of security and being active in shaping knowledge. PPPA in the Field of Child Development shows a form of student expectations in the home learning program [25].

Teachers usually use messaging programs such as Skype, Adobe Connect, or a webcam, to interact with guest speakers and other experts. There is increased maintenance and superior results when during the elearning, the video was used. The systematic development of video making methods is promising for making video models that have a positive impact on student learning. Computers, tablets, and mobile devices the latest technology has resulted in the development of Desktops, laptops, Tablets, which are widely used in the market. These tools have contributed greatly to learning and have allowed students and teachers to access websites and other programs, such as Microsoft office, PowerPoint, Excel, and images.

Various online learning applications that can be used in virtual classes. One of them is a blog. Blogs are discussion sites or information published on the World Wide Web and are usually displayed with the latest posts appearing first. The blog can be used by individual users as well as community users. The design of virtual classrooms has been facilitated by webcams. A video camera is a tool that presents images in real time via a computer or computer network. When captured by a computer, the video is stored, viewed, or sent to another network via a system such as the internet. It can also be sent to a remote location. using Wi-Fi connected by a USB cable, FireWire cable, or similar cable, or integrated computer hardware, such as a laptop.

This media provides an opportunity for users to share layers directly from the software and make online videos so that teachers and students can make live video shows [26]. Online learning of the content aspect can use email too. Email can be used to communicate and has a place to pin grades online, online exams. This is favoured by students and teachers because of the more flexible and faster use of time, as well as an attractive visual appearance [27].

The WhatsApp application is familiar for us. Before the application of online learning, this application was used for regular communication with family and friends and even colleagues. We also often use it to get information, the latest news from within the country and abroad. For some creative teachers, WhatsApp can also be used to teach lectures online, namely by recording learning from the teacher to the class group then each student can enjoy the learning video to gain knowledge. This is a smart and effective way in a pandemic like now. This application can also provide benefits for online learning to share video channels that may be useful in adding to the knowledge needed during learning. For example, sharing a YouTube link that contains material and even practice in learning. This application is very helpful for learning from home that can be done anytime, anywhere with an online system. All can be done with a good internet network. Some students find the difficulties to participate in e-learning; this gap is seen across countries and among income groups within peoples [25].

\subsection{Teacher Competence}

Teacher competence is all things knowledge, skills, attitudes that the teacher has wholeheartedly in carrying out his professional duties. Ten competencies in teachers in carrying out their professionalism according to P3G, namely: (a) mastery of teaching materials, (b) managing the teaching and learning process, (c) managing the classroom environment, (d) using media/learning resources, (e) mastery of educational foundations, (f) management of teachinglearning interactions, (g) assessing learning achievement, (h) recognize extension guidance functions and services, (i) recognize and organize school administration, (j) understand and assess research results for teaching purposes [29].

Teacher competence and learning infrastructure are important in the learning process. Likewise, in online learning. Professional teacher competence can increase student motivation. Motivation to learn is important in creating passion and enthusiasm for learning. With good enthusiasm and passion for learning, students will succeed in obtaining meaningful learning. So that the professionalism of teachers has a big influence on student achievement. 
In addition to teacher competence, a good learning environment is also needed to support a conducive learning environment that can help students get learning that is intelligent and meaningful. The creation of meaningful learning with a good learning environment must be supported by high teacher competence [31].

At the time of the current pandemic, teaching staff such as teachers must be more creative so that their students continue to study during school holidays because of a pandemic like this, while the school year continues, where each student takes lessons with less time compared to before a pandemic like this. Teachers must also teach according to the 2013 curriculum, so that everything that is desired in the curriculum is carried out even during a pandemic like this. [45]

The 2013 curriculum emphasizes the role of the teacher as a facilitator in learning. Unlike the previous curriculum where teachers still have a central role in learning. The 2013 curriculum which is oriented towards determining students as the centre of learning enables the teacher as a facilitator to play a maximum role. Many thinks that due to the 2013 curriculum, students are the centre of learning, the teacher has a lot of time to find the right formula in formulating learning plans. But in fact, in some literature it is found that the competence of teachers in utilizing technology-based learning media is still constrained by several things and can be said to be unable to keep up with technological developments because they still use traditional methods. Some of the obstacles faced by teachers in the use of media are experience and age factors. Teachers or educators do not have much ability in using online learning media. The reluctance of teachers to increase their knowledge of technology is also hampered by the age factor and the opportunity to acquire skills in technology [32].

Some teacher competencies that can be developed in online learning are increasing the learning experience flexibly according to the learning style, determining the efficiency in compiling instructional learning content, providing and supporting the ease of learning that is complex, supporting "participatory" learning, providing individual and different instructions. through various feedback mechanisms, it is possible to learn the same content at different speeds or to achieve different learning goals [27].

Table 2. Research on teacher competence

\begin{tabular}{|l|l|l|l|}
\hline \multicolumn{1}{|c|}{ Author \& Year } & \multicolumn{1}{|c|}{ Purpose of Studies } & \multicolumn{1}{c|}{ Method } & \multicolumn{1}{c|}{ Conclusions } \\
\hline $\begin{array}{l}\text { M-E.Johnson,L- } \\
\text { M.Elreda, 2020 }\end{array}$ & $\begin{array}{l}\text { Test the effect of teacher } \\
\text { competence in the learning } \\
\text { process in class }\end{array}$ & $\begin{array}{l}\text { Proportional } \\
\text { random } \\
\text { sampling }\end{array}$ & $\begin{array}{l}\text { The teacher determines how the } \\
\text { learning process takes place. the } \\
\text { quantity and quality of teaching it carries } \\
\text { out. Educators are a source of } \\
\text { knowledge so that with good skills and } \\
\text { knowledge, teachers can solve class } \\
\text { problems well. }\end{array}$ \\
\hline $\begin{array}{l}\text { R- } \\
\text { V-L.Walker, M- }\end{array}$ & $\begin{array}{l}\text { know the effect of teacher } \\
\text { environment on student } \\
\text { achievement }\end{array}$ & $\begin{array}{l}\text { Proportional } \\
\text { random } \\
\text { sampling }\end{array}$ & $\begin{array}{l}\text { There is a positive and significant effect } \\
\text { of teacher professional competence on } \\
\text { student achievement }\end{array}$ \\
\hline Jon Dron, 2018 & $\begin{array}{l}\text { To find out which learning } \\
\text { not }\end{array}$ & $\begin{array}{l}\text { Multilevel } \\
\text { analysis }\end{array}$ & $\begin{array}{l}\text { Smart learning is not only a smart } \\
\text { teacher but must be supported using } \\
\text { tools, methods with appropriate } \\
\text { procedures, to produce meaningful } \\
\text { learning. Teachers play an important } \\
\text { role in developing techniques and } \\
\text { strategies to motivate students to learn } \\
\text { intelligently. Smart teachers must be } \\
\text { able to provide ample opportunities for }\end{array}$ \\
\hline
\end{tabular}




\begin{tabular}{|c|c|c|c|}
\hline \multirow[t]{2}{*}{ Author \& Year } & Purpose of Studies & Method & Conclusions \\
\hline & & & $\begin{array}{l}\text { learners to connect, be supported and } \\
\text { students give each other opportunities } \\
\text { to learn. }\end{array}$ \\
\hline $\begin{array}{l}\text { P-M.Bigatel } \\
2013\end{array}$ & $\begin{array}{l}\text { Knowing the learning model } \\
\text { and the stages of the } \\
\text { approach carried out in the } \\
\text { types of online components }\end{array}$ & Experiment & $\begin{array}{l}\text { Teachers are required to understand the } \\
\text { online learning approach by combining } \\
\text { various types of online learning } \\
\text { components, namely online content, } \\
\text { interactive e-lessons, electronic } \\
\text { simulations, job aids. } \\
\text { Online learning resources non- } \\
\text { interactive resources such as documents; } \\
\text { interactive e-lessons linear sequence } \\
\text { which can include text, graphics, } \\
\text { animation, audio; Electronic simulations } \\
\text { are highly interactive forms online; }\end{array}$ \\
\hline $\begin{array}{l}\text { J.Guo, Y.Tong, } \\
\text { W.Pang } 2020\end{array}$ & $\begin{array}{l}\text { Apply teacher competencies } \\
\text { in E-Learning learning }\end{array}$ & $\begin{array}{l}\text { Proportional } \\
\text { random } \\
\text { sampling }\end{array}$ & $\begin{array}{l}\text { Teacher competence that educators } \\
\text { must possess to conduct online learning } \\
\text { is the ability to create instructional } \\
\text { designs. In accordance with the } \\
\text { pedagogical principles outlined in the } \\
\text { learning plan, mastering technology in } \\
\text { learning, namely the use of the internet } \\
\text { as a learning resource in order to obtain } \\
\text { up to date and quality teaching material } \\
\text { and master learning material (subject } \\
\text { meter) in accordance with the area of } \\
\text { expertise possessed. }\end{array}$ \\
\hline
\end{tabular}

\subsection{Student-Teacher Interactions,} Technology, and Teacher Competence in Creating Meaningful Online Learning Environments.

A meaningful learning environment is a personalized learning environment that forms learning with appropriate and meaningful methods, procedures. Meaningful learning is not only a smart teacher but must be supported using tools, methods with proper procedures, so as to produce meaningful learning [27].

Teachers play an important role in developing techniques and strategies to motivate students to learn intelligently. Smart teachers must be able to provide ample opportunities for learners to connect, be supported and students give each other opportunities to learn. Student-teacher interactions based on frequency and quality will produce student teacher relationships that include dimensions of attitude and support.38 Interaction has a role in the success of learning in the classroom. Good interaction will generate benefits for students and positive learning outcomes. With good interaction, warm and sensitive produce good reasoning. Student teacher interaction in learning can provide high language and reasoning skills.

A meaningful online learning environment is realized from all aspects of a quality learning environment. The interactions that occur in learning are supported by the ability of teachers and students to use technology and the competence of qualified 
teachers. The ability of teachers is not only smart in terms of academics, but also from a psychological aspect. So that the teacher can formulate a smart and meaningful learning.

Teachers can be more adaptive in providing learning online because they provide relatively flexible time. Even discussions can continue at any time because they are discursive and interesting because online learning can be interactive and interesting for students and teachers. Online learning also facilitates interactive activities due to feedback. The use of technology in online learning is not without problems. Many things hinder the implementation of effective and efficient learning [42].

Some of the obstacles in online learning are: (1) Mastery of information technology by teachers and students. The ability of teachers in Indonesia to not master technology is found in teachers born before the 1980s. This constraint limits teachers with a further age in using technology-based learning media. It also limits students who have significant obstacles. This is related to students who have limited access to technology so that their understanding of the use of technology is also low. (2) Media in the form of inadequate facilities and infrastructure. Technological devices are expensive and can only be reached by certain areas, so that many regions in Indonesia, both teachers and students, have difficult economic conditions. This is directly proportional to their opportunity to access information technology which is indispensable for online learning during this pandemic. (3) Limited internet network access is not equally distributed throughout the country. Both primary and secondary schools, have not been able to enjoy the internet. Sometimes the internet network has not been able to meet the fulfilment of the technology media [45]. (4) lack of budget availability. Budget costs can also be a barrier because access to technology and the internet has a lot of costs. One of the most worrying obstacles is the welfare of teachers so that the fulfilment of online learning needs is obstructed. Buying internet quotas, technology tools or media is difficult for teachers to have [43].

Strategic Steps and Solutions for Indonesian Education. In handling the impact of Covid-19 on the world of education, all elements must help each other in overcoming it. This condition cannot be separated from the perspective of government policies and the implementation of operationalization in the field. The things that must be done by all elements of education are:

\section{a. Government}

The role of government is very important and fundamental. The budget allocation that has been decided by Presidential Instruction Number 4 of 2020 concerning refocussing of activities, relocation of budgets, and procurement of goods and services in order to accelerate the handling of Covid-19 must be implemented immediately [44].

\section{b. Parents}

Parents as primary educators in the household must carry out their functions. Even so, teacher assistance in schools needs to be present door to door for all students. This must open the horizons and responsibilities of parents that their children's education must be returned to the parents' efforts in educating the mental, attitude and knowledge of their children.

\section{c. Teachers}

Online learning steps should be as effective as possible. The teacher does not burden students with tasks that are delivered in studying at home. If necessary, the teacher comes with ideas in the door to door of the students. The teacher is not only positioned as a transfer of knowledge.

\section{d. School}

Schools as educational providers must be prepared to facilitate any changes regarding the education of their students. Behavioural education must become a strong foothold during technological developments and the accelerated flow of information. Educational programs carried out by schools must really be conveyed to students, especially with online media, but the school must really pay attention to ethics as an educational institution. Emphasis on learning at home to students must be properly monitored so that teachers who teach through crisp media remain smooth and smart in delivering lessons that must be understood by students [46].

\section{CONCLUSION}

Overall, online learning environments allow learning to occur in an environment that is not limited by place or time. Online learning can dismantle barriers built by poverty, location, disability, and others. Current challenges, solutions and projections in online learning have not yet created good studentteacher interactions, mastery of technology and teacher competence in formulating meaningful learning cannot yet be said to answer all the obstacles to online learning. 
The interaction between students and teachers is still lacking in this regard, according to the survey it was stated that students were not satisfied with learning outcomes during online learning. The material and methods of online learning cannot be obtained directly by students. The competence of teachers who are lacking in mastering technology, no online teaching experience creates an atmosphere of online learning that is not conducive plus educators have not obtained the right online learning strategies to create meaningful learning. The obstacles that students and teachers find in online learning are heavier towards technology due to the availability of inadequate internet quotas, unstable networks, and supporting devices such as devices and laptops. If we relate it more broadly, online learning is very ineffective if it is applied in Indonesia which incidentally still uses conventional systems. The technology in less time becomes obsolete which is why students must improve electronic equipment. The technology in less time becomes obsolete which is why students must improve electronic equipment. The equipment used for learning is expensive. Some technologies are not very user friendly. Online learning as the effect of the COVID-19 pandemic gives a detrimental impression on meaningful learning that has an impact on student learning outcomes. In principle, the varied learning model during the Covid19 pandemic was considered good, but training is needed to support the ability of teachers to use technology and proficiency in choosing the best strategies and approaches in shaping meaningful learning. So that with online learning with good teacher-student interactions, mastery of technology, teacher competence can realize meaningful learning. However, behind the online learning, there are not only things that are detrimental, but also imply a good impression so that it can change the face of Indonesian education to become more modern.

\section{REFERENCES}

[1] World Health Organization (WHO), Points of Entry and Mass Gatherings, Retrieved, March 28, 2020, Accessed on: Sept. 8 2020. [Online]. Available:

https://www.who.int/emergencies/diseases/novel -coronavirus-2019/technical- guidance/pointsof-entry-and-mass-gatherings

[2] Rebekah K. Nix, B.J. Fraser, C.E. Ledbetter, Evaluating an integrated science learning environment using the constructivist learning environment survey, in: Learning Environments Research, vol. 8, Springer, Berlin, Heidelberg,
2005, pp.109-133. DOI: https://doi.org/ $\underline{10.1007 / \mathrm{s} 10984-005-7251-\mathrm{x}}$

[3] P.M. Bigatel, The Identification of Competencies for Online Teaching Success, Journal of Asynchronous Learning Networks 16 (2012) 5977.

[4] D. Zhang, J.L. Zhao, L. Zhou, J.F. Nunamaker, Can E-Learning Replace Classroom Learning?, Communications of The Association for Computing Machinery (ACM) 47 (2004) 75-79. DOI: https://doi.org/10.1145/986213.986216

[5] C.N.C. Ahmad, S.A. Shaharim, M.F.N.L. Abdullah, Teacher-Student Interactions, Learning Commitment, Learning Environment and Their Relationship with Student Learning Comfort, Journal of Turkish Science Education 14(1) (2017) 57-72.

[6] H.C. Fujimoto, A Multimodal Analysis of Teacher-Student Interactions in Reading Recovery Writing Sessions, 2020.

[7] D. Bouhnik, T. Marcus, Full-Text Citation Analysis: A New Method to Enhance, Journal of the American Society for Information Science and Technology 57 (2013) 64. DOI: https://doi.org/10.1002/asi.20277

[8] C. Turley, C. Graham, Interaction, Student Satisfaction, and Teacher Time Investment in Online High School Courses, Journal of Online Learning Research 5(2) (2019) 169-198.

[9] M. Krishnamurthi, Enhancing Student -Teacher Interactions in Internet-based Courses, Northern Illinois University, 2016.

[10] A. Sun, X. Chen, Online Education and Its Effective Practice: A Research Review, Journal of Information Technology Education: Research 15 (2016) 157-190. DOI: https://doi.org/10.28945/3502

[11] S.L. Christenson, C. Wylie, A.L. Reschly, Handbook of Research on Student Engagement, Springer Science, Berlin, 2018.

[12] J.T. Downer, M. Stuhlman, J. Schweig, J.F. Martínez, E. Ruzek, Measuring Effective Teacher-Student Interactions from a Student Perspective: A Multi-Level Analysis, Journal of Early Adolesence 35 (2015) 722-758. DOI: https://doi.org/10.1177/0272431614564059

[13] J. Cadima, T. Leal, M. Burchinal, The Quality of Teacher-Student Interactions: Associations with 
First Graders' Academic and Behavioral Outcomes, Journal of School Psychology 48(6) (2010) 457-482. DOI: https://doi.org/10.1016/j.jsp.2010.09.001

[14] S.S. Liaw, H.M. Huang, Perceived Satisfaction, Perceived Usefulness, and Interactive Learning Environments as Predictors to Self-Regulation in E-Learning Environments, Computers and Education 60(1) (2013) 14-24. DOI: https://doi.org/10.1016/j.compedu.2012.07.015

[15] G. Hagenauer, S.E. Volet, Teacher-Student Relationship at University: An Important Yet Under-Researched Field, Oxford Review of Education 40(3) (2014) 370-388. DOI: https://doi.org/10.1080/03054985.2014.921613

[16] D. Laurillard, Teaching as A Desain Science: Building Pedagogical Patterns for Learning and Technology, Balancing the Media: Learning, Media and Technology, Routledge, 2012.

[17] A. Alenezi, The Role of e-Learning Materials in Enhancing Teaching, International Journal of Information and Education Technology 10(1) (2020) 48-56. DOI: https://doi.org/10.18178/ijiet.2020.10.1.1338

[18] E-M.B. Avila, M.C.E. Mayorga, Virtual Environments and Meaningful English Language Learning as Second Language L2 in High School Students: A Case Study, INNOVA Research Journal 5 (2020) 64-78 DOI: https://doi.org/10.33890/innova.v5.n3.2.2020.15 $\underline{52}$

[19] M. Kokoç, A. Altun, Effects of Learner Interaction with Learning Dashboards on Academic Performance in An E-learning Environment, Behaviour \& Information Technology (2019). DOI: https://doi.org/10.1080/0144929X.2019.168073 $\underline{1}$

[20] C.W. Cook, C. Sonnenberg, Technology and Online Education: Models for Change, Contemporary Issues in Education, Research 7(3) (2014) 171-188 DOI: https://doi.org/10.19030/cier.v7i3.8638

[21] R.C. Pianta, J.E. Whittaker, V. Vitiello, E. Ruzek, A. Ansari, T. Hofkens, J. DeCoster, Children's School Readiness Skills Across The Pre-K Year: Associations With Teacher-Student Interactions, Teacher Practices, and Exposure to Academic, Journal of Applied Developmental Psychology,
66 (2020) 1-10. DOI:

https://doi.org/10.1016/j.appdev.2019.101084

[22] M. Kosma, N. Erickson, C.J. Savoie, M. Gibson, Skill Development Versus Performativity among Beginners in Aerial Practice: An Embodied and Meaningful Learning Experience, Policy, Theory and Social Issue 4(2) (2020) 173-187. DOI: https://doi.org/10.1177/0272684X20918053

[23] L.A. Pesonen, A. Piirainen, Teacher Students' Meaningful Learning in Widening, Journal of Teaching Education, (2019). DOI: https://doi.org/10.1080/10476210.2018.1561662

[24] E.Aboagye, J-A.Yawson, K-N.Appiah, COVID19 and E-Learning: The Challenges of Students in Tertiary Institutions, Social Education Research 2 (2021) 75-102.

[25] H.E. Johnson, L.M. Elreda, A.K. Kibler, V.A.F. Ehrlich, Creating Classroom Communities in Linguistically Diverse Settings: Teacher Directed, Classroom Level Factor Effects on Peer Dynamics, Journal of Early Adolescence 40 (2020) 1087-1120. DOI: https://doi.org.10.1177/027243161989123

[26] R.C. Pennington, V.L. Walker, M.C. Tapp, Teacher Preparation in Communication Instruction for Students with Extensive Support Needs, Teacher Education and Special Education (2010) 1-16.

[27] J. Nyika, F. Mwema, Conceptualizing Student Engagement and Its Role in Meaningful Learning and Teaching Experiences, Research gate (2020) 159-161.

[28] Titus Corlatean, Risks, Discrimination and opportunities for education during the times of COVID-19 pandemic, in: Research Association for Interdisciplinary Studies (RAIS) Conference Proceedings, vol. 1, RAIS publishing, Princenton, New Jersey, 2020, pp. 37-46. DOI: https://doi.org.10.5281/zenodo.3909867

[29] M. Thahir, A. Komariah, K.H. Asri, Widiawati, C. Sunanengsih, The leadership capacity of the principal in improving the quality of learning during the Covid-19 pandemic, in: Advances in Social Science, Education and Humanities Research, Proceedings of The $4^{\text {th }}$ International Conference on Research of Educational Administration and Management (ICREAM 2020) vol. 526, Atlantis Press, Paris, 2021, pp. 
$160-165$.

DOI:

https://doi.org/10.2991/assehr.k.210212.034

[30] P.M. Bigatel, L.C. Ragan, S. Kennan, J. May, B.F. Redmond, The Identification of Competencies for Online Teaching Success, Journal of Asynchronous Learning Networks 16 (2012) 55-79.

[31] M. Ebner, S. Schön, C. Braun, M. Ebner, Y. Grigoriadis, M. Haas, P. Leitner, B. Taraghi, COVID-19 Epidemic as E-Learning Boost? Chronological Development and Effects at An Austrian University against The Background of The Concept of E-Learning Readiness, Journal of Future Internet 12(94) (2020) 1-20.

[32] N.Hanani, Meaningful learning reconstruction for millennial: Facing competition in the information technology era, in: IOP Conference Series: Earth and Environmental Science, IOP Publishing, Bristol, 2020, pp. 1-10. DOI: https://doi.org.10.1088/1755-1315/469/1/012107

[33] K. Anwar, S. Asari, R. Husniah, C.H. Asmara, Students' Perceptions of Collaborative Team Teaching and Student Achievement Motivation, International Journal of Instruction 14(1) (2020) 325-344

DOI: https://doi.org/10.29333/iji.2021.14119a

[34] L.V. Neto, P.H.F.F. Junior, R.A. Bordini, J.L. Otsuka, D.M. Bede, Design and Implementation of An Educational Game Considering Issues for Visually Impaired People Inclusion, Smart Learning Environments 7(4) (2020). DOI: https://doi.org/10.1186/s40561-019-0103-4

[35] C. Retzlaff-Furst, Biology Education \& Health Education: A School Garden as A Location of Learning \& Well-being, Universal Journal of Educational Research 4(8) (2016) 1848-1857.

[36] M.S.R. Montoya, D.C.R. Hernández, Inverted Learning Environments with Technology, Innovation and Flexibility: Student Experiences and Meanings, Journal of Information Technology Research 9(1) (2016) 18-33. DOI: https://doi.org.10.4018/JITR.2016010102

[37] A. Buma, E. Nyamupangedengu, Investigating Teacher Talk Moves in Lessons on Basic Genetics Concepts in A Teacher Education Classroom, African Journal of Research in Mathematics, Science and Technology Education 24 (2020) 92-104. DOI: https://doi.org.10.1080/18117295.2020.1731647
[38] M.F. Fortune, M. Spielman, D.T. Pangelinan, Student's Perception of Online or Face to face Learning and Social Media in Hospitality, Recreation and Tourism, MERLOT Journal of Online Learning and Teaching 7(1) (2011) 1-16.

[39] B. Xua, N.S. Chen, G. Chen, Effects of Teacher Role on Student Engagement in WeChat-Based Online Discussion Learning, Journal Pre-proof 157 (2020) 1-20. DOI: https://doi.org/10.1016/j.compedu.2020.103956

[40] D.T. Bressington, W. Wong, K.K. Claire Lam, W.T. Chien, Concept Mapping to Promote Meaningful Learning, Help Relate Theory to Practice and Improve Learning Self-Efficacy in Asian Mental Health Nursing Students: A mixedmethods pilot study, Nurse Education Today 60 (2018) 47-55 DOI: http://dx.doi.org/10.1016/j.nedt.2017.09.019

[41] J. Guo, Y. Tong, W. Pang, Teachers' Perceptions of Students' Creativity in China's Classrooms: The Role of Students' Academic Achievement and Misbehaviors, The Journal of Creative Behavior 0(0) (2020) 1-1. DOI: https://doi.org.10.1002/jocb.448

[42] L.S.L. Vera, E.M.S.A. Laz, Collaborative Work to Build Meaningful Learning in Basic General Education International Journal of Psychosocial Rehabilitation 24(10) (2020) 2978-2992. DOI: https://doi.org.10.37200/IJPR/V24I10/PR30031 $\underline{3}$

[43] C. Turley, C. Graham, Interaction, Student Satisfaction, and Teacher Time Investment in Online High School Courses, Journal of Online Learning Research 5 (2019) 169-198.

[44] J.M. Daniel, L.E. Kim, Does Teacher Burnout Affect Students? A Systematic Review of its Association with Academic Achievement and Student-Reported Outcomes, International Journal of Educational Research 105 (2020) 1-12 DOI: https://doi.org.10.1016/j.ijer.2020.101714

[45] H. Ryu, B. Zhut, Creating and Assessing an Academic Learning Community between Biology and Statistics Courses, Problems, Resources, and Issues in Mathematics Undergraduate Studies (PRIMUS) (2020) 1-29 DOI: https://doi.org.10.1080/10511970.2020.1861141

[46] H.J.M. Pennings, T. Hollenstein, TeacherStudent Interactions and Teacher Interpersonal Styles: A State Space Grid Analysis, The Journal of Experimental Education 88 (2020) 382-406. DOI:https://doi.org.10.1080/00220973.2019.157 8724 